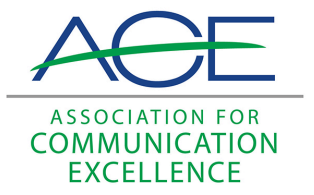

Journal of Applied Communications

\title{
CommunicAids Aids Communication: Newsletter Teaches Oregon Extension Workers to Be Better Communicators
}

Joyce Patterson

Follow this and additional works at: https://newprairiepress.org/jac cc) (ㅇ)

This work is licensed under a Creative Commons Attribution-Noncommercial-Share Alike 4.0 License.

\section{Recommended Citation}

Patterson, Joyce (1988) "CommunicAids Aids Communication: Newsletter Teaches Oregon Extension Workers to Be Better Communicators," Journal of Applied Communications: Vol. 71: Iss. 2. https://doi.org/10.4148/1051-0834.1552

This Research is brought to you for free and open access by New Prairie Press. It has been accepted for inclusion in Journal of Applied Communications by an authorized administrator of New Prairie Press. For more information, please contact cads@k-state.edu. 


\title{
CommunicAids Aids Communication: Newsletter Teaches Oregon Extension Workers to Be Better Communicators
}

\author{
Abstract \\ The Oregon State University Agricultural Communications faculty prepares a monthly newsletter with \\ information about communication methods and materials. In 1987 it evaluated the newsletter to \\ determine effectiveness as a way to teach Extension workers to be better communicators. Following \\ random selection procedures, a written questionnaire was sent to every third person who receives the \\ newsletter. Statistically, the reponse was $100 \%$. The one person who did not respond was no longer on the \\ staff. Ninety percent of the respondents replied that the newsletter is useful and the length of the articles \\ about right. Forty-nine percent use the annual index to look up previous articles. Respondents made \\ suggestions, which the writers have followed, such as punching the newsletter for three-ring binders and \\ printing on white rather than on colored paper. Respondents also suggested topics for future articles, \\ upon which the writers are acting.
}

This research is available in Journal of Applied Communications: https://newprairiepress.org/jac/vol71/iss2/4 


\title{
CommunicAids Aids Communication: Newsletter Teaches Oregon Extension Workers to Be Better Communicators
}

\author{
by Joyce Patterson
}

The Oregon State University Agricultural Communications faculty prepares a monthly newsletter with information about communication methods and materials. In 1987 it evaluated the newsletter to determine effectiveness as a way to teach Extension workers to be better communicators. Following random selection procedures, a written questionnaire was sent to every third person who receives the newsletter. Statistically, the reponse was $100 \%$. The one person who did not respond was no longer on the staff. Ninety percent of the respondents replied that the newsletter is useful and the length of the articles about right. Forty-nine percent use the annual index to look up previous articles. Respondents made suggestions, which the writers have followed, such as punching the newsletter for three-ring binders and printing on white rather than on colored paper. Respondents also suggested topics for future articles, upon which the writers are acting.

When I was in graduate school in the 1970s I took an Extension Methods class in which the students practiced using one Extension method to teach another Extension method. If I didn't know then, I certainly know now that Extension teems with methods. Some work better than others for certain applications.

As a communication specialist, my interest now is learning which methods are most useful in helping Extension workers develop communication skills.

Nice as it might be to have a communication specialist in each county office, the next best thing is to teach Extension agents and specialists to become better communicators. A communications newsletter, coupled with in-service training, is one way that some states, including Oregon, help workers foster development and growth of their own communications skills (Laurent, 1986).

Budget cutbacks in 1981 that reduced travel for training programs nudged Oregon State University (OSU) Agricultural Communications Office into launching CommunicAids, a monthly newsletter. CommunicAids includes information about communication methods and materials to support Extension work around the state. The newsletter is distributed with three supplements: news of the latest Extension and Experiment Station publications, an in-depth "backgrounder" to help the reader become more proficient at communication-related skills, and a sheet on computer use.

Six years and 74 issues later, in the summer of 1987, the OSU agricultural communications staff decided it was time to formally evaluate how effective CommunicAids is as an Extension method to teach Extension methods.

Joyce Patterson is an ACE member, and associate professor and Extension communication specialist, Agricultural Communications, Oregon State University. 
CommunicAids has tried to teach its readers that communication is a twoway process, with feedback being an important part. In the case of written material, feedback is not immediately obvious. It may be observed in reactions such as letters to the editor, personal letters to the writer, adoption of the idea in some plan of action, personal comments, and telephone calls (Babcock, 1957).

The agricultural communications staff had observed much of this informal feedback over the years. But it was time to formalize the process and ask the audience how they thought we were doing. Is CommunicAids on the mark? Does it meet their needs? Is it an effective way to provide training? Is it worth the resources?

As Hadley Read (1972, p. 300) wrote, "For any communication effort....we can afford to spend just so much money, time, and effort. [Therefore, the] objective is to achieve the highest possible output per unit of input."

If CommunicAids isn't helping Extension workers become better communicators, we would need to find a new way to teach communication skills because the need is greater than ever for these workers "to strengthen [their] expertise as professional educators" (Astroth and Robbins, 1987, p. 10).

\section{Evaluation Objectives}

The primary objectives of our evaluation were to determine if CommunicAids is meeting recipients' needs; if it is an effective way to provide training; and if it is worth the resources put into it. We also hoped to learn if recipients keep and refer to earlier issues. (If not, it might be appropriate to repeat topics).

\section{Methodology}

We designed a written questionnaire with 16 questions. ${ }^{1}$ Respondents could answer 14 of the questions by circling appropriate answers. One question asked the respondent to suggest subjects for future issues, and the final question was open ended, asking if there was anything else to be noted about CommunicAids. The questionnaire was pre-tested with three groups: agricultural communications staff, on-campus Energy staff, and the Benton County Extension staff. We refined the questionnaire after each pre-test.

Following random selection procedures, we sent the questionnaire to every third person who receives CommunicAids. We mailed 124 questionnaires and received 123 responses. A personal letter from the office director accompanied the questionnaire. The letter explained that the questionnaire would take about five minutes to fill out; that the recipient had been selected randomly; that his or her response was important because it represented other readers, as well; and that the enclosed return envelope was numbered so reminders could be sent those who didn't respond but that the respondent's anonymity would be preserved because the completed questionnaire would be separated from the envelope when it reached agricultural communications' office.

The month before the questionnaire was mailed, an article in CommunicAids alerted readers to the fact that one-third of them would be receiving the questionnaire.

Two weeks after the questionnaire was mailed, we sent a follow-up, personal letter from the office director with another copy of the questionnaire https://newprairiepress.org/jac/vol71/iss2/4

DOI: 10.4148/1051-0834.1552 
to those who had not responded. Two weeks after the first follow-up, a second follow-up personal letter and questionaire were sent. (The office director added hand-written, personal notes to many recipients, which probably contributed to the high number of questionnaires returned.) Two weeks after we mailed the second follow-up, we telephoned the two people who had not responded. One of these people was found to be no longer on the staff. The other responded.

\section{Summary of Results}

Most CommunicAids readers are Extension agents (40\%), Extension specialists (24\%), and secretaries (20\%). The remaining $16 \%$ are Experiment Station researchers, administrators, and "others." Sixty-one percent have held their positions longer than five years.

More than three-fourths $(76 \%)$ read CommunicAids regularly; $16 \%$ read it occasionally. Most $(71 \%)$ read it when it arrives. Ninety percent find it useful. They find the "Backgrounder" the most useful supplement, but all supplements are useful to more than half of the readers.

The accompanying table shows the level of interest that respondents indicated in specific topics that have appeared in CommunicAids.

Table 1. Level of Interest in Subjects Covered in CommunicAids

$\%$ Responses

\begin{tabular}{lcccc}
\hline & High & Medium & Low & Don't know \\
\hline Radio techniques & 16 & 28 & 55 & 0 \\
Video techniques & 27 & 42 & 28 & 1 \\
Exhibits & 25 & 42 & 29 & 4 \\
Photography tips & 45 & 29 & 24 & 2 \\
Publications & 35 & 32 & 30 & 3 \\
$\quad$ ordering info & 63 & 30 & 6 & 0 \\
Writing tips & 18 & 40 & 40 & 1 \\
Tips on preparing & 33 & 39 & 24 & 4 \\
$\quad$ PSAs & 37 & 37 & 23 & 3 \\
Marketing ideas & & & & \\
Success stories & & & & \\
How to plan and & 41 & 42 & 17 & 0 \\
$\quad$ promote an event & & & & 1 \\
$\quad$ or activity & 35 & 38 & 21 & 3 \\
Speechmaking tips & & & & \\
OSU policies & & & & \\
\hline
\end{tabular}

Other topics that respondents suggested would be of interest include writing for journals, using desktop publishing, working with media, managing offices, improving telephone skills, developing listening skills, working with agricultural communications, and preparing flyers. One respondent indicated an interest in seeing examples of what other agents are doing. Another respondent requested a section for secretaries. One respondent said a similar 
newsletter from the Agricultural Fiscal and Personnel Office with reminders on office procedures would be useful.

Ninety percent of readers said the length of the articles is about right, and nearly as many $(89 \%)$ said the length of each issue is about right. However, in written comments, three readers suggested that less frequent publication or a shorter publication would be acceptable if it would prevent "burnout" among the agricultural communications staff.

Nearly half the respondents added written comments to the questionnaire. One reader mentioned that articles are often discussed at staff meetings. Three respondents suggested that articles are too basic.

Forty-nine percent have used the index to look up previous articles, and four readers clip and file articles of special interest to them. Nearly half would like CommunicAids punched to put in a three-ring binder. (In the pre-test, one respondent said if we punch it to be sure to use the large-hole punch).

\section{Summary}

The survey told us that we are doing a lot of things right and that a newsletter works as an Extension method to teach other methods. But we learned of several changes we can make that will improve CommunicAids. We've already accepted suggestions to punch for three-ring binders and to print it on white stock for those who want to recycle the paper and for those who like to photocopy articles. We've expanded distribution to all Agricultural Experiment Station branch faculty. We've written articles about requested topics such as telephone skills.

In response to a reader who criticized, "Topics are random and don't address particularly important topics," we will use a year-long planning cycle for at least some major subjects.

We'll make more changes, and CommunicAids readers have been told that they're always welcome to suggest what these ought to be. After all, feedback about all Extension methods is important.

\section{References}

Astroth, K.A., \& Robbins, B.S. (1987). Recess is over. Journal of Extension, $25,10-12$.

Babcock, C. Merton (1957). The Harper handbook of communication skills. New York: Harper \& Brothers.

Laurent, Mary F. (1986). Communications Newsletters and Extension: A Survey. ACE Quarterly, 69(2), 9-15.

Read, H. (1972). Communication methods for all media. Urbana: University of Illinois Press.

1The survey, the full 10-page summary and a sample copy of CommunicAids are available from the author upon request. 